\title{
ASSESSING THE IMPACTS OF SOCIAL NETWORKING SITES AMONG PAKISTANI YOUTH
}

\author{
Hira Ahmad Farrah \\ Research Scholar, Department of Sociology, University of Agriculture, Faisalabad \\ hira.murtaza07@gmail.com
}

\author{
Muhammad Tahir \\ Lecturer, Department of Sociology Karakoram International University Diamer Campus Chilas \\ mtahir20@gmail.com
}

\author{
Shuja-ur-Rehman \\ Assistant Professor, Department of Sociology, Karakoram International University, Diamer Campus \\ Chilas
}

\begin{abstract}
Social media has become a strong agent of socialization in contemporary era among youth throughout the world. It has been observed that social media is used as an influential tool for framing opinion formation in social activism and connect people together. In this study, 180 students of two universities of Faisalabad district have been included by using multistage sampling technique. It has been designed to assess the impact of social networking websites on the youth. Use of social media in Pakistan is steadily increasing and it is imperative to assess and analyze behavioral, social and economic effects it produces on the younger population. It also enables to determine the benefits, or otherwise, of the indulgence in the social networks. Three hypotheses were developed while univariate and bi-variate analysis have been performed. It is concluded that younger students compared to mature one, are more attentive towards their studies. The realistic approach towards career/life is directly related to the higher level of education, and also to higher incomelearning of the subjects.
\end{abstract}

Keywords: Youth, Social networking sites (SNS), Unrealistic approach, Lack of attentiveness,

\section{INTRODUCTION}

The modern era largely depends on social networking, and it has become essential in present times. There are millions of people, especially youth, who use sources of social networking for multiple purposes like relationship, business and infotainment (Tahir, 2015). These social networking tools substantially impact the lives of youth. Social networking sites (SNSs) are explained by Boyd (2007) as web elements that allow users to (1) create a profile. (2) provide platform for persons to express and share their feelings, and (3) visualize and check other users' profiles and views within the set framework (Nicole, 2011). These sites not only allow people to know each other, search and communicate with like-minded persons but also permits to develop communities and share data (Haythornthwaite, 2005). These sites vary according to their specifications or features, "Classmate.com" website was developed in 1995 by Randy Conrad which maintains contact between friends, peers and colleagues to share information with one another. Advanced Social Networking sites, for instance, Facebook and Google offer socializing and communication (Valkenburg et al., 2011). Online inter-connection is the most recognized means to socialize, augment business and to retrieve statistics for any specific parameter. Baker (2016) concluded that almost $67 \%$ young people use internet or such media for some specific purpose whereas $22 \%$ of them have no such specific reasons. All age group people utilize these websites for various purposes or for fun only. From sending and receiving messages to conference / video calling for sharing pictures and videos/ recordings, all are done using these smart tools of the modern world. It appears that negative impact outweighs the positive on modern-day youth. The physical effects of overuse of electronic gadgets result in chronic ailments like migraine and development of visual impairment. Real and physical Individual relationships are diminishing with the development of such type of long range virtual communication. The old concept of social interaction between individuals or groups of people is 
getting low without the realization of its consequences. It is observed that uncalled-for incidents of misuse or abuse are increasing thus jeopardizing the peaceful lives of the legal (Zay, 2010). Wastage of time by the youth is a big issue leading to profoundly devastating effects on their education and competency. The larger the group of such youth, the greater is the dimension. Apart from its academic deleterious effects, it is also impinging on the business of closeness of family ties (P.M. Valkenburg et al, 2011). However, these social groups working on various websites are fostering provision of platform to develop not only academic communication but also discussion of various topics of mutual interest enabling the participants to put forth their point of view, creating a healthy competitive ambience. It also provides means for youth to exchange personal information, like profiles and pictures, providing opportunity to break gender barriers. Crossing these barriers leads to numerous interpersonal problems which are aggravated by unbridled contact between young boys and girls causing many sexual and behavioural problems. These adolescences attempt various gimmicks to attract each other's attentions. A few underage children of either sex share picture with their companions while partying, drinking liquor, smoking cigarettes and doing indecent acts. Such conduct is not only harmful for them in the long run but also, they influence immature minds of others. It is usually suggested to be something "new" "hot" and "in". It is also implied that the young ones who do not comply with these new trends are "old-fashioned" and belong to "old school idea" group. This attitude appears to be rebellious, whereas these same youngsters could utilize these media to share occasions of mutual interest like sharing their birthday pictures, information about enjoying the long summer break, excursions to historical places and sites of religious importance (Jong \& Drummond, 2016). These long-range communication platforms are basically the real media of today and are expanding day by day quite quickly. This case study is aimed at the people who are influenced by such long-range communication platforms, and it reveals that externalities and inspiration of people to join such forums exhaust by every passing day. Some people use these sites just for fun and others for pleasure and it remains the central point of this myth. However, at the flipside, a lot of others use these channels for constructive purpose. Further, ladies use these locales comparatively more than men. Still more, the sexual orientation distinction has a great influence on the user of a person-toperson communication locale (Lin, 2011). Major objective of the study is to determine the likelihood of usage of SNSs by highly educated students for either educational or recreational purposes and to determine the effects of SNSs on them.

\section{REVIEW OF LITERATURE}

Rfeqallah (2021) discovered that the majority of students utilize social networking sites for socializing rather than academic purposes. The researcher, on the other hand, was interested in the relationship between the goals for which students use social media sites and the respondents' perceptions of their academic success. This suggests that as the usage of social media for academic purposes grows, so does the positive perception of academic success

Abbas (2019) explored the association between positive and negative characters of social media and university students' learning attitudes for long-term education. Social networking sites and their applications increasingly appear to offer huge benefits as well as threats to university students, and their effects on students' psychological adjustment.

Latifa (2012) studied the effects of interpersonal interaction locales on young persons and it was discovered that these channels decrease the time spent in family get to gather. It was also discovered that these open-up new avenues to study and discuss matters hitherto unexplored and thus undefined. Social behaviors were profoundly influenced by these channels.

Raoof et al., (2013) reported that the online networking endpoints like Facebook, Twitter and YouTube play an important role in airing political opinion. Disinformation assists in developing a political strategy and in planning and caring out of political campaign and motivating the voters and supporters. Similarly, the electorate can use these websites to evaluate and compare the various contenders. It was shown in study that individuals correspond through these channels to contemplate the various issues raised by different campaigners and the solution offered by them. Advancement in use of these channels was observed after 2008 presidential race won over by Obama of United States. This wholly brought to surface the centrality of the web systems in political arenas.

According to Raza's (2020) found that the urge to preserve interpersonal connectedness, entertainment value, and social enhancement value prevent students' engagement in social networking 
sites, where they experience both social benefit and useless engagements. The existence of social benefit increases life satisfaction, however unnecessary social activities decrease life satisfaction among students

Zareen (2014) conducted the study at university of Gujrat determine the role of social networks, particularly Facebook, in assessing the political acumen of the students and any effect it produced in their political understanding. This study tries to determine the largest using division of the University of Gujrat of Facebook. The pupils of CS / IT were found to be most frequent user. 67 males and 53 females were assessed out of which $65 \%$ were aged $22-24$ years whereas $30 \%$ were 19 - 21 years old, $56.7 \%$ of subjects belong to urban zone, $30 \%$ were sub-urban while only $13.3 \%$ belong to the common zone.

In another study Kanagavel and Chandrasekaran (2014) studied the personal behavior of the subjects and the effect on the communicating parties on many issues, there appeared to be divisive approaches. This study also detected that there was tremendous sharing of political ideas and views among the adult subjects of Tamil Nadu.

Some researchers investigated the impact of SNS in Sharing and Communication of data in Distance Education. It was suggested that these websites are more beneficial when knowledge is disseminated under the supervision of instructors. This medium provides adequate opportunities to the learners for direct communication with their educators and clarifies any ambiguities. It was implied that these SNSs create addictive attitudes while facilitating the share of information, direct correspondence and becoming a way of life (Zhang \& Leung, 2015).

Shabir et al., (2014) discovered that interpersonal collaboration provided a stage to address and discuss issues which are circumstantially disregarded. 300 young subjects were investigated. The essential targets were (1) to look at the effects of online networking in creating social falsehood. (2) To certain the benefits of online networking for the youth. (3) to survey the tendency of the youth towards interpersonal communication and the measurement of determining the value of internet communication. (4) To recommend measures for the use of interpersonal communication towards the prompt education of general populace. It was found that the majority of the subject involved in this study agreed to be beneficial effect of online networking. Majority of the respondents appreciated that Facebook was the favorite interpersonal communication structure and after that skype was considered to be the second best in this domain. Forty-six percent of the respondents applauded the role of PC lab which offers easy accessibility to the persons who could not afford to possess their personal computer. Some of the subjects were fearful regarding the undesirable effects of wayward messaging and considered it detrimental to spread of valuable communication. It was suggested that appropriate measures must be enforced to curb unfavorable and undesirable information. The dissemination of improper pictures and videos by unscrupulous elements must also be dealt with a heavy hand. The unrestricted and antagonistic posting of sectarian and ethnocentric content on social media lead to development of sectarian, religious and racial hatred between various sections of society. Moreover, the diplomatic, trading and social relationships between countries having differences are further computed by negative propaganda and venomous material against one another.

Hillbun (2019) narrated that, Youngsters use social networking sites (SNSs) to share their life experiences with their peers, including their consuming experiences that is connected to their materialistic ideals. He further found that this experience shapes their perceptions and social relationship. He suggested that young adults' self-control and close relationships with their parents may help to mitigate the negative effects of social media use.

Teenagers use social networking websites with intentions of Self-harming and suicidal tendencies to seek emotional support from other users. They receive negative vibes, and face selfinjurious behavior of other users, and adopting self-harm techniques via shared films, online social networking leads to greater exposure to and engagement in self-harm behavior. They further found that spending more time on social networking sites causes psychological discomfort, unmet mental health needs, and suicide ideation (Memon et al., 2018).

\section{METHODOLOGY}

This study was designed to find out the impact of social networking sites on the youth age (19-24). This study was conducted in Faisalabad district of Punjab. With the help of simple random sampling two institutions were selected for this study: 
a. Govt. College University Faisalabad (GCUF) 75

b. University of Agriculture Faisalabad (UAF) 105

A sample of 180 students was subjected. Data was collected by distributing 105 questionnaires to UAF subjects and 75 questionnaire forms GCUF with the help of proportionate sampling technique. A purposefully designed questionnaire comprising of closed- and open-ended questions was utilized for data collection. Descriptive analysis techniques such as frequency distribution, percentage distribution, uni-variate analysis and bi-variate analysis were made by using SPSS version-20. Each significant was tested with the help of Gamma test and chi-square analysis.

\section{Uni-variate Analysis}

The information was classified into meaningful categories by developing frequency distribution tables. Averages and percentages were calculated for better understanding of facts and figures.

\section{Bivariate Analysis}

Bivariate analysis was performed to test the direction of relationship between two variables. For testing of the association and correlation between variables Chi-Square and Gamma tests were applied. The Chi Square test measures the association between two variables.

$\chi^{2}=\sum \frac{(\mathrm{O}-\mathrm{E}) 2}{E}$

Gamma test is used to check the strength and direction of the relationship between independent and dependent variables

Gamma $=\frac{N s-N d}{N s+N d}$

The bi-variate analysis tests the following three hypotheses:

\section{Hypothesis 1:}

Association between the respondent's age and their perception about lack of attentiveness on their studies.

\section{Hypothesis 2:}

Association between the respondent's education and their perception about unrealistic approach

\section{Hypothesis 3:}

Association between the respondent's income or pocket money and their perception about unrealistic approach about their life

\section{RESULTS AND DISCUSSION}

\section{Socio-economic characteristics of respondents}

Age is a significant demographic element among socio - economic characteristics and it has influence on the behaviour and in enhancing the understanding of the person through experience. The power of decision making and appropriate use of resources is influence by it. Education is an essential and basic human right, being a very crucial requirement for the socio-economic development of any nation. Employment of technology for imparting education has a constructive impact on the students. The monthly income indicates the economic condition of a person. This Study revealed that about $25 \%$ of the subjects were $19-20$ years of age while $40 \%$ were $20-21$ years old. $63.8 \%$ of the study population were males whereas $36.2 \%$ were females.

Age is very important demographic element among socio-economic characteristics of an individual as it influences one's behavior and widens the vision of an individual through experience. It maintains its effects on the decision making and wise use of available resources. Education is a basic human right and integral for socio-economic development. The use of technology in education has had a positive impact on the students

Study exposed that around 8 per cent of respondents were eighteen years old and 20 percent 22 years old. About 36 per cent of them were male and 64 per cent female. It displays that around half of the respondents were the students of B.S (honor) while 20 percent of M.A / M.Sc. 29 per cent of the parents and almost 23 percent fathers holding Govt. job. This study also revealed that $55 \%$ of the subjects lived in joint family system, $0.33 \%$ in a nuclear family and only $12 \%$ in an extended family. It was also found that $13 \%$ of the subjects have low pocket money/ income while $17 \%$ have more than 10000 rupees as pocket money or income. It was detected that $88 \%$ of the subjects had their own cell phones and $67 \%$ had laptops. 
Table No. 1 Demographic Profile

\begin{tabular}{|l|l|l|}
\hline Characteristics & Frequency & Percentage \\
\hline Age & & \\
\hline $19-20$ & 45 & 25.0 \\
\hline $21-22$ & 72 & 40.0 \\
\hline $23-24$ & 63 & 35.0 \\
\hline Gender & 115 & \\
\hline Male & 65 & 63.8 \\
\hline Female & & 36.2 \\
\hline Education & 29 & \\
\hline B.Sc. / B. A & 89 & 16.2 \\
\hline B.S (honor) & 36 & 49.4 \\
\hline M.Sc. /M. A & 26 & 20.0 \\
\hline M.Phil. & & 14.4 \\
\hline Family type & 91 & \\
\hline Joint family & 21 & 55.0 \\
\hline Extended family & 60 & 11.7 \\
\hline Nuclear family & & 33.3 \\
\hline Pocket money / Income & 40 & \\
\hline 1-2000 & 23 & 22.2 \\
\hline 2001- 4000 & 36 & 12.7 \\
\hline 4001-6000 & 24 & 20.0 \\
\hline 6001-8000 & 57 & 13.3 \\
\hline More than 8001 & & 31.8 \\
\hline Ownership & 159 & \\
\hline Cell phone & 63 & 88.3 \\
\hline Notepad & 103 & 35.0 \\
\hline Desktop & 37 & 57.2 \\
\hline Laptop & 17 & 20.6 \\
\hline Tablet & 9.4 \\
\hline
\end{tabular}

The above table is based on the Uni-variate analysis and shows $62.20 \%$ respondents are using social networking sites about 1-3 hours daily and less than half percent of them are using social networking sites about 1-3 hours in a week. More than $1 / 3$ percent respondents are using social networking sites about 1-3 hours at night and less than half i.e. 46 percent respondents are using the social networking sites more than 12-hours in a week. This study reveals that majority of respondents i.e. $85 \%$ from youth are using social networking sites with their Cell phones while only 5 percent with the notepads. A huge number of respondents i.e. 90 percent are using Facebook for socializing with friends and family and about 3/4 of Population i.e. 72.8 percent are using WhatsApp while 1/3 percent of population are using Viber for communication with their peer group.

Table No. 2: Trends of Using SNSs

\begin{tabular}{|l|l|l|}
\hline Characteristics & Frequency & Percentage \\
\hline Time spending daily & & \\
\hline 1-3 hours & 112 & 62.0 \\
\hline 3-6 hours & 30 & 16.7 \\
\hline 6-9 hours & 21 & 11.7 \\
\hline 9-12 hours & 7 & 3.9 \\
\hline More than 12 hours & 10 & 5.5 \\
\hline SNSs used by respondents & & \\
\hline Skype & 81 & 45.0 \\
\hline
\end{tabular}




\begin{tabular}{|l|l|l|}
\hline YouTube & 116 & 64.4 \\
\hline Facebook & 163 & 90.6 \\
\hline WhatsApp & 131 & 72.8 \\
\hline Viber & 57 & 31.7 \\
\hline Instagram & 64 & 35.6 \\
\hline Google++ & 122 & 67.8 \\
\hline Yahoo & 67 & 37.2 \\
\hline Twitter & 62 & 34.4 \\
\hline
\end{tabular}

The information with respect to the instructive level of the respondents uncovers that less than half percent of population use social networking sites for entertainment by watching online films, dramas, talk shows etc. Less than half percent of population say that they mostly use social networking sites for getting latest information and current news around the world. It shows more than $1 / 3$ percent of the population says that they frequently use social networking sites for playing games on their electronic devices like laptop, desktop, cell phones etc. About 44 percent of youth representatives use social networking sites repeatedly just for time pass and 42 percent says that they habitually use social networking sites just for sharing their pictures with their family and friends. Exactly half of the population use social networking sites for sharing religious information to others and 46 percent says that they frequently use social networking sites to watch national Geographic's and TLC's documentaries for getting knowledge of other countries and communities. Majority of the respondents i.e. 44 percent says that they use social networking sites for family interaction or communication. Social networking sites are really very useful for getting latest research information from all over the world. About half of the population agrees with this result while 2 respondents strongly disagree with this statement. In this era political knowledge is also integral for the youth less than half of the respondents agree with the statement that they get political awareness from the social networking sites. This study shows 42 percent respondents agree that they adopt new ideas from these social networking sites.

Table No. 3 Effects of SNSs on Youth

\begin{tabular}{|l|l|l|}
\hline Characteristics & Frequency & Percentage \\
\hline Information & & \\
\hline To great extent & 86 & 47.8 \\
\hline To some extent & 77 & 42.8 \\
\hline Not at all & 17 & 9.4 \\
\hline Entertainment & & \\
\hline To great extent & 84 & 46.7 \\
\hline To some extent & 79 & 43.9 \\
\hline Not at all & 17 & 9.4 \\
\hline For family interaction & & \\
\hline To great extent & 57 & 31.7 \\
\hline To some extent & 79 & 43.9 \\
\hline Not at all & 44 & 24.4 \\
\hline For studies & & \\
\hline Strongly agree & 71 & 39.4 \\
\hline Agree & 86 & 47.8 \\
\hline Neutral & 17 & 9.4 \\
\hline Disagree & 4 & 2.2 \\
\hline Strongly Disagree & 2 & 1.1 \\
\hline
\end{tabular}

Due to SNSs, youth are more inclined towards smoking habit 30 per cent are strongly agreed with this statement. More than $1 / 3$ of respondents are agreed with the statements that due to SNSs, youth are more inclined towards obesity. About 40 per cent are agreed with the statements that because of SNSs, youth are suffering with eating disorder while 5.6 per cent are strongly disagree with this statement. Due to SNSs youth is suffering with sleeping disorder, 40 per cent of respondents 
are strongly agreeing with the statement. This study reveals that about 40 per cent of respondents are strongly agree with the statement that due to SNSs youth is spending less time with family members. About 45 per cent of respondents are agreed with the statement that SNSs are better for the society and less than 1/5 are strongly agreed with it. Less than half of the respondents are agree with the statement that SNSs are creating awareness among youth. Around 50 per cent are agreed with the statement that SNSs are the source of getting knowledge and exactly $1 / 3$ are strongly agree with it. According to respondents' perception, youth have irresponsible behaviour due to SNSs and about 45 per cent are agreed whit this statement.

\section{Hypothesis 1:}

Table No. 4 Association between the respondents' age and their perceptions about lack of attentiveness on their studies

\begin{tabular}{|c|c|c|c|c|c|c|}
\hline \multirow{2}{*}{$\begin{array}{l}\text { Respon } \\
\text { dent's } \\
\text { Age } \\
\end{array}$} & \multicolumn{5}{|c|}{ Lack of Attentiveness } & \multirow[t]{2}{*}{ Total } \\
\hline & Strongly Agree & Agree & Neutral & Disagree & Strongly Disagree & \\
\hline \multirow{2}{*}{$18-20$} & 17 & 32 & 7 & 1 & 5 & 62 \\
\hline & $27.4 \%$ & $51.6 \%$ & $11.3 \%$ & $1.6 \%$ & $8.1 \%$ & $100.0 \%$ \\
\hline \multirow[b]{2}{*}{$20-22$} & 15 & 24 & 10 & 10 & 0 & 59 \\
\hline & $25.4 \%$ & $40.7 \%$ & $16.9 \%$ & $16.9 \%$ & $0.0 \%$ & $100.0 \%$ \\
\hline \multirow{2}{*}{$22-24$} & 14 & 23 & 14 & 8 & 0 & 59 \\
\hline & $23.7 \%$ & $39.0 \%$ & $23.7 \%$ & $13.6 \%$ & $0.0 \%$ & $100.0 \%$ \\
\hline \multirow{2}{*}{ Total } & 46 & 79 & 31 & 19 & 5 & 180 \\
\hline & $25.6 \%$ & $43.9 \%$ & $17.2 \%$ & $10.6 \%$ & $2.8 \%$ & $100.0 \%$ \\
\hline
\end{tabular}

$\begin{array}{llll}\text { Chi-Square }=21.18 & \text { D.F. }=8 & \text { P-Value }=.007 & \text { Gamma }=.118\end{array}$

To check the relationship between the respondents' age and lack of attentiveness on studies, Gamma test and Chi-Square test are applied. The chi-square value shows direct and strong relationship between respondents' age and lack of attentiveness on studies. The Gamma value shows that there is strong direct relationship between respondents' age and lack of attentiveness on studies. Therefore, the hypothesis "Higher the respondents' age lowers is the attentiveness on studies" is acknowledged. It means elder students give less attention to their studies while the younger pays more attention to their studies and get good academic grades.

\section{Hypothesis 2:}

Table No. 5 Association between the respondents' education and their perceptions about unrealistic approach

\begin{tabular}{|l|l|l|l|l|l|l|}
\hline $\begin{array}{l}\text { Respondent' } \\
\text { s Education }\end{array}$ & Perception about Unrealistic Approach about their life & Total \\
\cline { 2 - 7 } & Strongly Agree & Agree & Neutral & Disagree & $\begin{array}{l}\text { Strongly } \\
\text { Disagree }\end{array}$ & \\
\hline \multirow{2}{*}{ B.Sc. } & 8 & 3 & 14 & 4 & 0 & 29 \\
\hline \multirow{2}{*}{ B. S } & $27.6 \%$ & $10.3 \%$ & $48.3 \%$ & $13.8 \%$ & $0.0 \%$ & $100.0 \%$ \\
\hline \multirow{2}{*}{ M.Sc. / M. A } & 14 & 44 & 26 & 4 & 1 & 89 \\
\hline \multirow{2}{*}{ M.Phil. } & $15.7 \%$ & $49.4 \%$ & $29.2 \%$ & $4.5 \%$ & $1.1 \%$ & $100.0 \%$ \\
\hline \multirow{2}{*}{ Total } & 0 & 13 & 6 & 7 & 0 & 36 \\
\hline & $0.0 \%$ & $36.1 \%$ & $16.7 \%$ & $19.4 \%$ & $0.0 \%$ & $100.0 \%$ \\
\hline
\end{tabular}

Chi-Square $=34.34 \quad$ D.F. $=12 \quad$ P-Value $=.001 \quad$ Gamma $=-.050$

To check the relationship between respondents' education and their perception about unrealistic approach about their life, Chi-square test and Gamma test were applied. The Chi-Square value shows strong relationship between respondents' education and their perceptions about 
unrealistic approach and their lives. The Gamma value demonstrates that there is strong inverse relationship between respondents' education and their perceptions about unrealistic approach and their lives. Thus, the hypothesis "Higher the respondents' education higher the perception about unrealistic approach and the lives they have" is acknowledged. It means highly qualified respondents had lowered the unrealistic approach about their lives and the less qualified respondents are more unrealistic about their lives.

\section{Hypothesis 3:}

Table No. 6 Association between the respondents' income or pocket money and their perceptions about unrealistic approach and their lives

\begin{tabular}{|l|l|l|l|l|l|l|}
\hline \multirow{2}{*}{$\begin{array}{l}\text { Respondent's } \\
\text { Income }\end{array}$} & \multicolumn{5}{|l|}{ Perception about Unrealistic Approach about their life } & Total \\
\cline { 2 - 7 } & Strongly Agree & Agree & Neutral & Disagree & $\begin{array}{l}\text { Strongly } \\
\text { Disagree }\end{array}$ & \\
\hline \multirow{2}{*}{$1000-5000$} & 17 & 38 & 22 & 6 & 1 & 84 \\
\cline { 2 - 7 } & $20.2 \%$ & $45.2 \%$ & $26.2 \%$ & $7.1 \%$ & $1.2 \%$ & $100.0 \%$ \\
\hline \multirow{2}{*}{$5000-10000$} & 8 & 30 & 24 & 4 & 0 & 66 \\
\hline \multirow{2}{*}{$10000-15000$} & $12.1 \%$ & $45.5 \%$ & $36.4 \%$ & $6.1 \%$ & $0.0 \%$ & $100.0 \%$ \\
\cline { 2 - 7 } & 4 & 8 & 5 & 2 & 0 & 19 \\
\hline \multirow{2}{*}{$15000-$ Above } & $21.1 \%$ & $42.1 \%$ & $26.3 \%$ & $10.5 \%$ & $0.0 \%$ & $100.0 \%$ \\
\hline \multirow{2}{*}{ Total } & $27.3 \%$ & 1 & 3 & 4 & 0 & 11 \\
\hline & 32 & $9.1 \%$ & $27.3 \%$ & $36.4 \%$ & $0.0 \%$ & $100.0 \%$ \\
\hline
\end{tabular}

Chi-square $=27.91 \quad$ D.F. $=12 \quad$ P-Value $=.006$ Gamma $=.236$

To discover the relationship between respondents' income and their unrealistic approach about their lives, the Chi-Square test and the Gamma test are applied. The chi-square value is 27.91which shows the strong relationship between respondents' income and unrealistic approach about their lives. The Gamma value is .236 which indicates that there is strong direct relationship between income of the respondents and unrealistic approach. Therefore, the hypothesis "Higher the respondents' income or pocket money lowers the unrealistic approach about their lives" is acknowledged. It shows the youth who has low income or pocket money are more realistic than the respondents who have high income or pocket money.

\section{CONCLUSION AND RECOMMENDATIONS}

Social Networking sources are the most commonly used platforms by the young people for interacting in different ways like socializing, exchanging and sharing pictures, exchanging information, ideas and opinions on political, religious as well as economic matters. Easy accessibility and simplicity of use has made social media a household affair. A large part of the day is spent by the youth utilizing the services of these social networks which suggest that contributing factors could be interpersonal communication through messaging, posts and status which unable transfer of data. Through these networks the younger population remain in touch with their companions, their beloved ones and also interact with other individuals. Inappropriate and for ulterior purposes usage of these networks could be detrimental. This study reveals that the younger the subjects the more attentive they are towards their studies but have an unrealistic approach towards life. It is also concluded that highly educated people have more realistic approach towards life, and it is further concluded that they are concentrated towards their education and goals. It is recommended to the government that measures should be taken to promote higher education to lend a direction to proper approach towards their social life by making them good citizens who are beneficial to the society. Government should also implement policies and provide incentives to the elderly people to acquire higher education. It is also the duty of parents to keep balance and vigilant eye on their children for enabling them more realistic towards their studies. 


\section{REFERENCES}

Abbas, J., Aman, J., Nurunnabi, M., \& Bano, S. (2019). The impact of social media on learning behavior for sustainable education: Evidence of students from selected universities in Pakistan. Sustainability, 11(6), 1683.

Ali, B. M. (2011). 'Effect of Social Networking Sites in Communication of Information in Distance Education'-A Literature Review.

Boyd, D. M., \& Ellison, N. B. (2007). Social network sites: Definition, history, and scholarship. Journal of computer-mediated Communication, 13(1), 210-230.

Haythornthwaite. N. (2005). Social Networking Sites. Retrieved November 25, 2011, from Webopedia:http://www.webopedia.com/TERM/S/social_networking_site.html

Jong, S. T., \& Drummond, M. J. (2016). Hurry up and 'like'me: immediate feedback on social networking sites and the impact on adolescent girls. Asia-Pacific Journal of Health, Sport and Physical Education, 7(3), 251-267.

Kanagavel, R., \& Chandraskaran. (2014). Creating Political Awareness through Social networking sites -An empirical Study with special reference to awareness from it, retrieved 13 June 2021, from http://libguides.library.cqu.edu.au/litreviewO

Latifa, K. (2012). The opinion of social sciences student of the Punjab University about T.V programs in Pakistan, Lahore: Master's thesis, department of Mass Communication, University of Punjab. Lahore.

Lin, K. Y., \& Lu, H. P. (2011). Why people use social networking sites: An empirical study integrating network externalities and motivation theory. Computers in human behavior, 27(3), $1152-1161$.

Memon, A. M., Sharma, S. G., Mohite, S. S., \& Jain, S. (2018). The role of online social networking on deliberate self-harm and suicidality in adolescents: A systematized review of literature. Indian journal of psychiatry, 60(4), 384-392

Raoof, K. J., Zaman, H. B., Ahmad, A., \& Al-Qaranghuli, A. (2013). Using social networking sites as a tool for political change. International Journal of Physical Sciences, 6(21):1143-1148

Raza, S. A., Qazi, W., Umer, B., \& Khan, K. A. (2020). Influence of social networking sites on life satisfaction among university students: a mediating role of social benefit and social overload. Health Education, 120(2): 141-164.

Rfeqallah, M., Kasim, R., Ali, F. A., \& Ghaffar, Y. A. (2020, December). The Effect of Using Social Networking Sites on Undergraduate Students' Perception and Academic Performance at University of Taiz-Yemen. In International Conference of Reliable Information and Communication Technology (pp. 987-998). Springer, Cham.

Shabir, G., Hameed, Y. M. Y., Safdar, G., \& Gilani, S. M. F. S. (2014). The impact of social media on youth: A case study of bahawalpur city. Asian Journal of Social Sciences \& Humanities, 3(4), 132-151.

Tahir, M., \& Shafi, B. (2015). The Impact of Electronic Media on Youth Behavior regarding Informal Education in Peshawar, KPK. City University Research Journal, 5(2), 349-358.

Valkenburg, et al. (2011). Retrieved 12 July 2021 from, https://www.sciencedirect.com/science/article/pii/S0747563216302059

Valkenburg, P. M., Peter, J., \& Schouten, A. P. (2006). Friend networking sites and their relationship to adolescents' well-being and social self-esteem. CyberPsychology \& behavior, 9(5), 584590.

Zareen, S., Arshad, A., \& Muhammad, A. J. (2014). Usage of Social Networking Sites: Interpersonal Communication Motives of Youth. Arts and Social Sciences Journal, 5:80

Zhang, Y., \& Leung, L. (2015). A review of social networking service (SNS) research in communication journals from 2006 to 2011. New media \& society, 17(7), 1007-1024. 